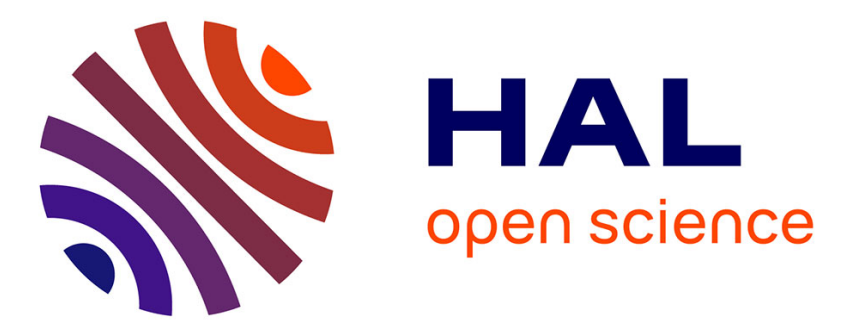

\title{
Comparison of Industry-Academia Partnership Projects for the Purpose of Product Development
}

\author{
Takashi Konishi, Kenju Akai, Nariaki Nishino, Kazuro Kageyama
}

\section{To cite this version:}

Takashi Konishi, Kenju Akai, Nariaki Nishino, Kazuro Kageyama. Comparison of Industry-Academia Partnership Projects for the Purpose of Product Development. IFIP International Conference on Advances in Production Management Systems (APMS), Sep 2015, Tokyo, Japan. pp.118-125, 10.1007/978-3-319-22759-7_14. hal-01431085

\section{HAL Id: hal-01431085 \\ https://hal.inria.fr/hal-01431085}

Submitted on 10 Jan 2017

HAL is a multi-disciplinary open access archive for the deposit and dissemination of scientific research documents, whether they are published or not. The documents may come from teaching and research institutions in France or abroad, or from public or private research centers.
L'archive ouverte pluridisciplinaire HAL, est destinée au dépôt et à la diffusion de documents scientifiques de niveau recherche, publiés ou non, émanant des établissements d'enseignement et de recherche français ou étrangers, des laboratoires publics ou privés. 


\title{
Comparison of Industry-Academia Partnership Projects for the Purpose of Product Development
}

\author{
Takashi Konishi*, Kenju Akai*, Nariaki Nishino*, and Kazuro Kageyama* \\ The University of Tokyo \\ konishita@giso.t.u-tokyo.ac.jp, akai@css.t.u-tokyo.ac.jp, Ni- \\ shino, atmi.t.u-tokyo.ac.jp, kageyamalgiso.t.u-tokyo.ac.jp
}

\begin{abstract}
The Japanese manufacturing industry has sought to increase its international competitiveness by developing higher value-added products. Simultaneously, R\&D that exploits external resources - as typified by open innovation - is also taking hold.

Although collaborative product development research between public research institutions and private-sector companies is widely conducted, there are many instances when the results are not achieved due to differing perceptions of the partnership. Under such conditions, especially when the research is publically funded, methods for better managing the projects are being sought at the policy level. Using examples of publically funded industry-academia collaborative projects, this paper considers efficient management methods for projects aimed at such development.

The research focuses on changes to the collaborative research system used in partnership projects and shows that it is more effective to conduct collaborative research that incorporates other companies as needed, without fixating on the original make-up of the collaborative system at the start.
\end{abstract}

Keywords: Industry-Academia collaboration, collaborative research system

\section{Introduction}

It has been shown that profitability among private companies in Japan's industrial sector is on a long-term, downward trend - even in the key industry of manufacturing. This is linked to the economy undergoing globalization as well as other major structural shifts on a worldwide scale, and the rapid rise of China and the rest of Asia exposing Japanese industry to greater competition. In order to address this situation and tap into the growth of the global economy, companies across the board are working to revamp manufacturing processes in their domestic and overseas plants and improve efficiency rates. Further, in recent years, as seen in Germany's national "Industry 4.0" strategy, greater use is being made of Information and Communications Technology to optimize domestic production sites. In addition, there are attempts underway to strengthen international competitiveness by shifting from the manufacturing of general-purpose goods to higher value-added products. This has created a need to focus on product development, which consists of pre-production processes such as concept development, design, and research, all critical in generating higher value-added products. Further, integrating R\&D and manufacturing processes is an effective way of producing higher value-added products, which are characterized by innovative features and groundbreaking quality. Therefore, policy changes that relate to product development in manufacturing encompass the need for new investment in R\&D.

adfa, p. 1, 2011.

(C) Springer-Verlag Berlin Heidelberg 2011 
However, presently, R\&D investment does not necessarily lead to increased company profits, thereby making the improvement of company profits through R\&D an issue that needs to be addressed. As a result, in addition to the traditional approach to $R \& D$ where companies work individually on basic research through to the product development, a new approach that incorporates the concept of open innovation is being advocated. This enables companies to minimize investment risk by cleverly exploiting intellectual property, R\&D know-how, and other technical skills possessed by other institutions, with a view to turning these into a commercial reality. The use of open innovation is being incorporated into manufacturing industries in Europe, the US, and across the rest of the world, and it is a concept that is becoming a common method of creating innovation $[1,2,3]$. Since translating basic research results into commercialization generally requires a large amount of time and money, conducting R\&D inhouse from the basic research stage entails a high level of investment risk. Therefore, importing technology from external institutions in the form of basic research results can be an effective way of reducing this risk. It is widely known that research institutions, such as universities, are knowledge hubs that conduct cutting-edge and creative research. It is for this reason that industry-academia partnerships involving collaboration between universities and private companies are seen as classic examples of open innovation [4, 5, 6, 7, 8]. In Japan, since 1983, when collaborative research between state-run universities and private-sector companies was institutionalized, the number of agreements has increased yearly, and the number of companies attempting to introduce ideas from public research institutions into their own product development is on the rise. A particularly rapid rise in collaborative research was seen after 1990, accompanied by steady increases in the budget to support public funding of such research. A similar trend in government policies promoting industry-academia partnerships has been seen not only in Japan but also across Europe and the US [9, 10, 11]. To date, there have been many case studies of effective approaches to managing industry-academia partnerships, which are considered important in raising the competitiveness of individual companies as well as strengthening the country's international competitiveness $[12,13,14,15,16,17]$. Some of these previous studies also relate to intellectual property [18] and look at funding for institutions involved in industryacademia partnerships.

Thus, while industry-academia partnerships are considered critical, they also present a challenge since the results of such partnerships often do not lead to the development of any specific products. Particularly in Japan, a major factor thought to cause this lack of success is the different perspectives of university researchers and researchers at private companies towards these joint research projects. This paper aims to demonstrate strategies for overcoming these challenges where such differences between researchers exist and effectively translating the results of joint research projects into product development.

\section{Program Introduction}

\subsection{Program Overview}


The program used for the analysis here is one of the industry-academia partnerships run by the Japan Science and Technology Agency (JST), which is one of Japan's funding agencies. JST handled this program from 2001 to 2010.

The system and structure of this program is largely characterized by three elements. First, it targets R\&D projects that are expected to translate, within a few years, research results from universities and other public research institutions into either a commercial reality or product development premised on subsequent commercialization, with the aim to build a laboratory-level prototype by the time of completion. Second, it involves three entities collaborating in the research - universities, private companies, and JST - with the university-affiliated researcher taking the lead role in the project. Third, JST provides funding to the amount of approximately 30 million yen per year over approximately three years. In addition, the JST program officer (PO) managing the overall program participates in the funded projects as a third party, and provides advice, information and other support from the perspective of commercial feasibility to efficiently advance the research. In some cases, it may be possible to change the collaborative research structure of the project, if deemed appropriate by the PO.

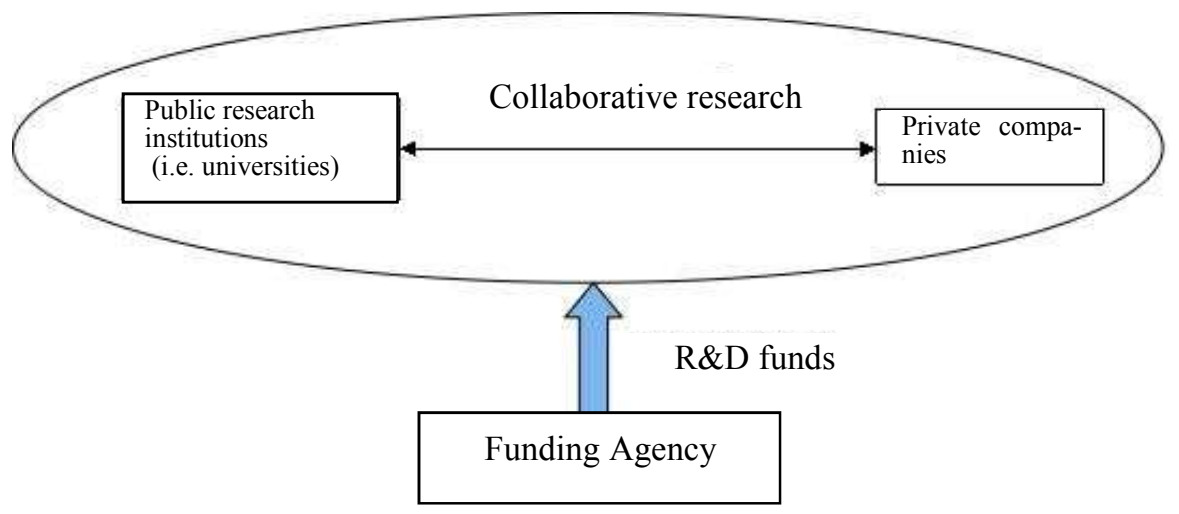

Fig. 1. Support system for collaborative research

\subsection{Ex-ante evaluation}

The ex-ante evaluation is conducted by a technology evaluation committee made up of eight external experts, based on the following three indicators: 1) novelty and superiority of the project, meaning the technological content of the research project is innovative and has a high level of superiority compared with other technology; 2) the usefulness of the results in terms of marketability and envisaged for potential commercialization; 3) appropriate research plans with a view to commercialization. Specifically, precise research plans aimed at practical applications are designed for a funding period of approximately three years. They are evaluated from the perspective of whether they have a high potential to succeed, whether the participating companies possess the technical skills required to advance the project and have clear roles, and 
the companies are suitable for yielding practical applications from the results. The adoption rates vary from year to year, but the trend is between $14 \%$ and $18 \%$.

\subsection{Ex-post evaluation}

The ex-post evaluation is conducted after the end of the funded period, again by a technology evaluation committee of eight external experts. The success achieved by each project is classified according to the following five indicators: (1) corporatization (including those still in preparation); (2) ongoing product development within a company; (3) venture establishment; (4) ongoing operation and the acquiring of other competitive funds; and, (5) ongoing collaborative research with a focus on universities, etc. The research project results are then evaluated based on project reports and comments received, examining, for example, the extent to which the plan was implemented, expected commercial viability, and acquisition of intellectual property rights..

\section{Method of Analysis}

\subsection{Projects Investigated}

The projects analyzed in this study are concluded projects that received funding between 2001 and 2004 (with collaborative research agreements from 2004 to 2007). According to project guidelines, there is no limit to the number of companies that can participate in each collaborative research project. Therefore, there are projects with a varied number of participating companies, from projects with only one to projects with multiple ones. Further, in some instances, the collaborative research systems adapt and change during the project, with other private companies joining the project or new companies being swapped in.Thus, as a method of expanding R\&D results, with an eye to effective practical application, this study analyzes the relationship between collaborative research systems and actual project achievements.

\subsection{Method of Analysis}

The analysis matches the status of each project, following the conclusion of funding, to the steps of a general linear R\&D model: applied research, product development, and commercialization. Further, it assigns point values to each step of the linear model to conduct a quantitative evaluation. The specific point values are as follows: 0 points for applied research as the initial value; 1 point for product development, which is considered one step up; and 2 points for commercialization, which is considered two steps up.

Meanwhile, although the status of each funded project immediately after conclusion differed, these were classified according to the following five shared indicators to demonstrate their status in greater detail: (1) corporatization (including those still in preparation); (2) ongoing product development within a company; (3) venture establishment; (4) ongoing operation and acquiring other competitive funds; and, (5) ongoing collaborative research with a focus on universities, etc. 
The study associated the steps and the status of each project, shown above, and quantified the performance of the projects.

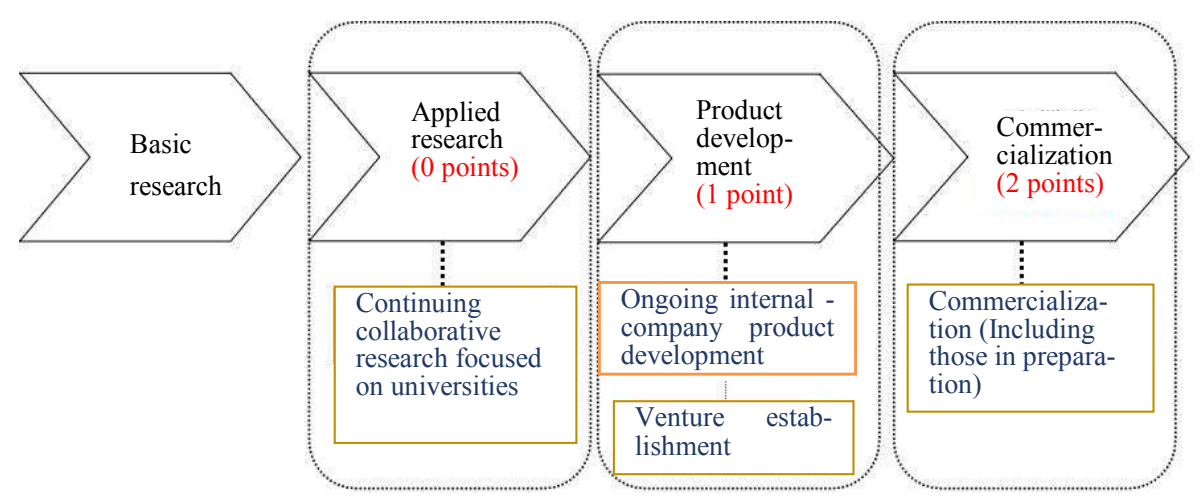

Fig. 2. Project status correlation diagram

\section{Results}

\subsection{Results by Project Structure}

Projects were separated into two groups: one group of projects that did not change their collaborative research systems by the time their support had ended and another group of projects that did change their systems. An average point value based on this status was calculated (Table 1). Furthermore, projects were compared based on the following grouping: projects that had only one company participating at the start of funding and projects that had two or more companies participating at the start of funding.

The analysis was established with two factors: changes or lack thereof to project structure (Factor 1), and whether or not only one company was participating at the start of the support (Factor 2). Accordingly, although the main findings are similar for Factor 1 and Factor 2, performing a two-factor analysis of variance guarantees that there is no interaction. 
Table 1. Points by project structure

\begin{tabular}{|c|c|c|c|}
\hline & & \multicolumn{2}{|c|}{$\begin{array}{l}\text { Collaborative research system at the start of } \\
\text { support }\end{array}$} \\
\hline & & $\begin{array}{l}\text { Project group with } \\
\text { one company partic- } \\
\text { ipating in collabora- } \\
\text { tive research (a) }\end{array}$ & $\begin{array}{l}\text { Project group with two } \\
\text { or more companies } \\
\text { participating in collabo- } \\
\text { rative research (b) }\end{array}$ \\
\hline $\begin{array}{l}\text { Group with no } \\
\text { changes to collabo- } \\
\text { rative research sys- } \\
\text { tems (A) }\end{array}$ & $\begin{array}{l}0.84 \\
(62,0.54,0.30)\end{array}$ & $\begin{array}{l}0.76 \\
(37,0.54,0.29)\end{array}$ & $\begin{array}{l}0.96 \\
(25,0.53,0.28)\end{array}$ \\
\hline $\begin{array}{l}\text { Group with changes } \\
\text { to collaborative } \\
\text { research systems (B) }\end{array}$ & $\begin{array}{l}1.37 \\
(19,0.48,0.23)\end{array}$ & $\begin{array}{l}1.29 \\
(7,0.45,0.20)\end{array}$ & $\begin{array}{l}1.42 \\
(12,0.49,0.24)\end{array}$ \\
\hline
\end{tabular}

Inside each cell, the top row shows the average points by project structure and the bottom row shows the sample size, standard deviation, and variance.

Table 2. Analysis of variance table

\begin{tabular}{|l|c|l|l|l|l|}
\hline Factor & $\begin{array}{l}\text { Sum of } \\
\text { squares }\end{array}$ & $\begin{array}{l}\text { Degrees of } \\
\text { freedom }\end{array}$ & $\begin{array}{l}\text { Mean } \\
\text { square }\end{array}$ & F & Notes \\
\hline Factor 1 & 4.13 & 1 & 4.13 & 14.58 & $\mathrm{p}<0.005$ \\
\hline Factor 2 & 1.43 & 1 & 1.43 & 5.06 & $\mathrm{p}<0.05$ \\
\hline Interaction & 0.00 & 1 & 0.00 & 0.00 & \\
\hline Residual & 22.12 & 78 & 0.28 & - & \\
\hline Overall & 27.68 & 81 & - & - & \\
\hline
\end{tabular}

\subsection{Effects of Restructuring Collaborative Research Project Systems}

In order to confirm the effects of changing collaborative research systems and bringing in companies from outside the projects, we compared projects that did not change their collaborative research systems to projects that did change their systems. From those results, the high numbers in the group that changed collaborative research systems revealed this as an effective method to create successful outcomes during the timeframe analyzed (i.e., finding new companies and incorporating them into the collaborative research systems).

\section{Case Study}

For our analysis, we examined a case study of a project that began as an 
industry-academia partnership, with a single development company, but went on to add another company later in the funding period to help advance to the product commercialization stage. The aim of this project was to develop a general-purpose device capable of nanofabrication. However, since the initially participating company produced special-specification devices to order, it did not have the capacity to expand its production and business operations to develop general-purpose products. This weakness in the collaborative research structure was identified at the start of the funding period. Two years into the project, with verification results at the prototype level positive, the PO and lead researcher reconfirmed the strategy for capitalizing on future results and began to search for another private company to participate. The lead researcher approached a company that had been involved in collaborative research as part of a separate project and had sufficient technology and business-related capacity for the needs of this project. The company evaluated the project's current research results and investigated whether or not its business strategy was compatible with the project. Based on a positive assessment, it decided to participate. This enabled the project to move forward towards its aim, which was to commercialize a general-purpose device capable of nanofabrication. For the original company, another company with a different business structure joining the project was a good opportunity to build collaborative relations with the new company. Specifically, the development company was tasked with the core parts for the general-purpose device under development.

\section{Conclusion}

For projects that did not change their collaborative research systems during the research process (i.e. add new companies or change the companies involved), having multiple companies participate at the start, (identifying practical applications within the technological scope of each company), was more effective than having a collaborative research system with only one company participating. Moreover, collaborative research systems that did change were highly effective from a product development standpoint, irrespective of the number of companies participating in the project at the start. One primary cause of this is that as R\&D progresses, the societal value of the potential results becomes clearer, which then clarifies which private companies should actually carry out the product development. This is not necessarily a disadvantage for the private companies already participating but rather could be considered favorable for future business, as technology can be licensed to other companies that may participate, bringing in profit from licensing and the transfer of intellectual property. 


\section{References}

1. Rigby, D., Zook, D.: Open-market innovation. Harvard Business Review 80, 10, 80-89 (2002)

2. Chesbrough, H.W.: Open Innovation: The New Imperative for Creating and Profiting from Technology. Harvard Business School Publishing, Cambridge (2003)

3. Christensen, J.F., Olesen M, H., Kjær J, S.: The industrial dynamics of open innovation - evidence from the transformation of consumer electronics. Research Policy 34, 10, 1533-1549 (2005)

4. Perkmann, M., Walsh, K.: University-industry relationships and open innovation: Towards a research agenda. International Journal of Management Reviews 9(4), 259-280 (2007).

5. Hershberg, E., Nabeshima, K., Yusuf, S.: Opening the Ivory Tower to Business: University-Industry Linkages and the Development of Knowledge-Intensive Clusters in Asian Cities World Development, 35(6), 931-940 (2007)

6. Cohen, W.M., Nelson, R.R. Walsh, J.P.: Links and impacts: the influence of public research on industrial R\&D. Management Science 48 (1), 1-23 (2002)

7. Mansfield, E.: Academic research and industrial innovation. Research Policy 20, 1-12. (1991)

8. Pavitt, K.: What makes basic research economically useful? Research Policy 20, 109-119.(1991)

9. Greenaway, D. Haynes, M.: Funding Universities to Meet National and International Challenges. Nottingham.School of Economics Policy Report, University of Nottingham (2000)

10. Stiglitz, J., Wallsten, S.: Public-private technology partnerships: promises and pitfalls. American Behavioral Scientist 43-73(1), 52 (1999)

11. Etzkowitz, H. Leydesdorff, L.: The dynamics of innovation: from National Systems and "Mode 2" to a Triple Helix of university-industry-government relations. Research Policy 29, 109-123 (2000)

12. Agrawal, A.: University-to-industry knowledge transfer: literature review and unanswered questions. International Journal of Management Reviews 3, 285302 (2001)

13. McMillan, G.S., Hamilton, R.D.: The impact of publicly funded basic research: an integrative extension of Martin and Salter. IEEE Transactions on Engineering Management, 50(2), 184-191 (2003)

14. Mowery, D.C., Nelson, R.R. (eds.) Ivory Tower and Industrial Innovation: University- Industry Technology Before and After the Bayh-Dole Act. Stanford University Press,. Stanford (2004)

15. OECD Benchmarking Industry-Science Relationships. Organisation for Economic Co-operation and Development, Paris (2002).

16. Poyago-Theotoky, J., Beath, J., Siegel, D.S.: Universities and fundamental research: reflections on the growth of university-industry partnerships. $\mathrm{Ox}^{-}$ ford Review of Economic Policy 18(1), 10-21 (2002)

17. Debackere, K., Veugelers, R.: The role of academic technology transfer organizations in improving industry science links. Research Policy 34(3), 321-342 (2005)

18. Hall, B.H.: University-industry partnerships in the United States. In Contzen, J.-P., Gibson, D., Heitor, M.V. (eds.) Rethinking Science Systems and Innovation Policies. Proceedings of the 6th International Conference on Technology Policy and Innovation. Purdue University Press, Ashland (2004). 